Article

\title{
Douro Carboniferous System: Integration of the Built Environment Heritage Aspect within the Territorial Planning Framework
}

\author{
Daniela Alves Ribeiro \\ Centro de Estudos de Arquitectura e Urbanismo da Faculdade de Arquitectura da Universidade do Porto, \\ Via Panorâmica, S/N, 4150-564 Porto, Portugal; dribeiro@arq.up.pt; Tel.: +351-22-605-71-00
}

Received: 30 November 2018; Accepted: 27 December 2018; Published: 5 January 2019

\begin{abstract}
In society energy is the most evident representation of the relationship between technology, economics, and culture and, therefore, formalizes itself in territorial transformations subjugated to the logic of its production, transportation, and consumption. Energy production based on what was the only Portuguese fuel-mineral coal-gave rise to the Carboniferous System of the Douro (Sistema Carbonifero do Douro (SCD)), extending from the social support structures close to the places it was mined to the (infra)structure systems of, and in, Porto (Portugal). Given this system, the relationship of it within the territory takes on particular importance in its understanding as heritage. The system seeks to reach conclusions about the integration of its heritage condition within territorial transformation policies. To do so, it seeks to understand how "structural invariants" which determine nuclei of this system are understood within the scope of the planning instruments and territorial management in force and, therefore, making conclusions regarding the mismatch between the recognition of heritage and its valorization of such as well as the difficulty of creating a prospective heritage understanding. As an alternative, the promotion of inclusive territorial management planning processes, which go beyond municipal management, capable of (re)producing territorializing actions that enhance and support heritage.
\end{abstract}

Keywords: Carboniferous System of the Douro; technological landscape; territorialization; built environment heritage; territorial planning; structural invariants; prospective heritage

\section{Introduction}

In society, energy is the most evident representation of the relationship between technology, economics, and culture and, therefore, formalizes itself in territorial transformations subjugated to the logic of its production, transportation, and consumption [1,2]. Energy production based on what was the only Portuguese fuel-mineral coal-gave rise to the Carboniferous System of the Douro (Sistema Carbonifero do Douro (SCD)) (1795-1994) [3], extending from the social support structures close to the places it was mined to the (infra)structure systems of, and in, Porto (Portugal).

Linked to Portugal's national desire to reflect the economic and social changes introduced by the Industrial Revolution, the actual need for energy autonomy meant that for decades the protection given to national fuel sources [4] made mining of coal in the Douro Coal Basin (Bacia Carbonifera do Douro (BCD)) [5], the base of this system, viable (Figure 1). 


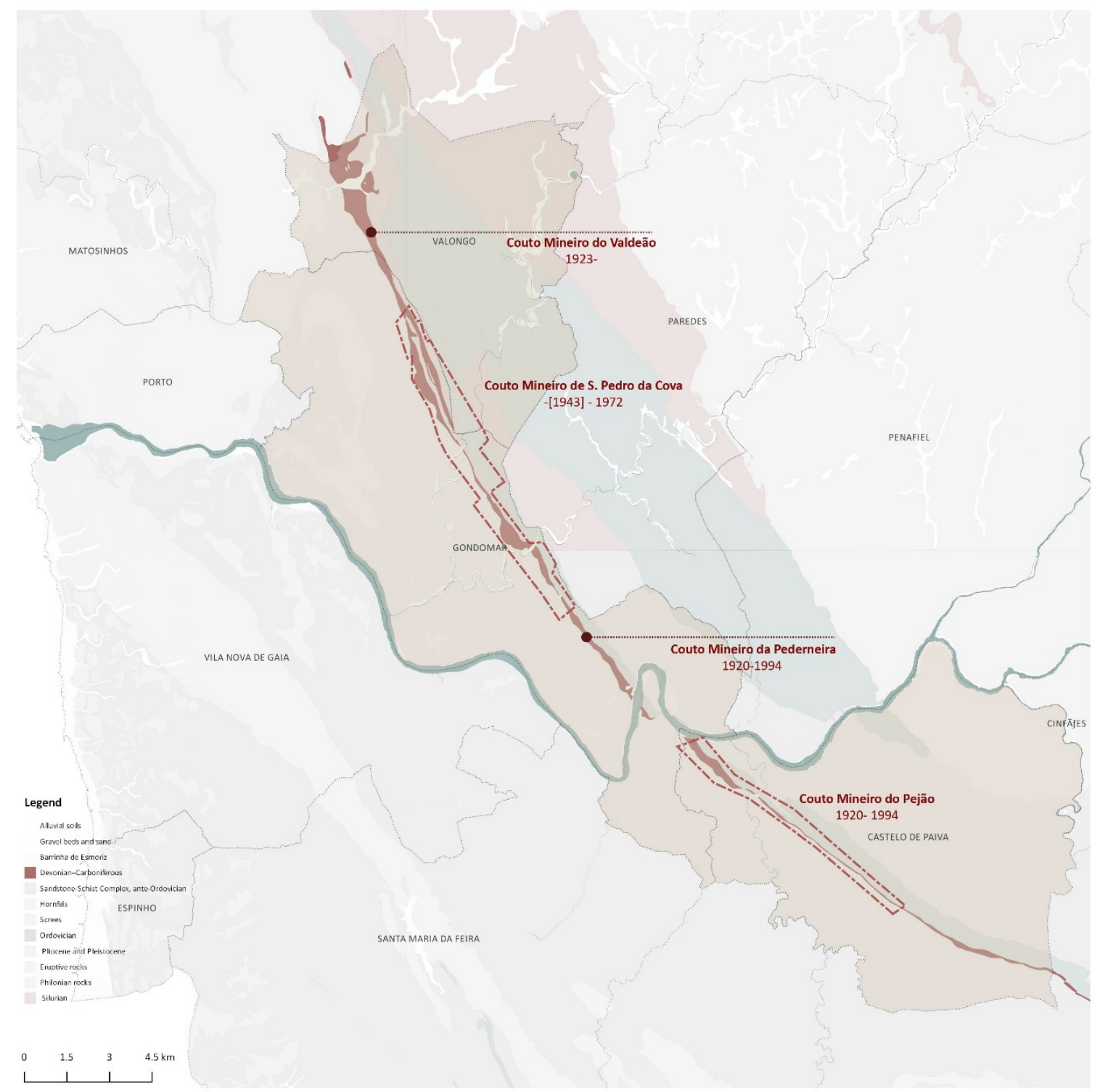

Figure 1. Pinpointing of the Douro Coal Basin (Bacia Carbonífera do Douro (BCD)) Coutos Mineiros region. It is demarcated by the mining areas of Couto Mineiro do Pejão and Couto Mineiro de S. Pedro da Cova.

The system is based on a "technological landscape" [6] resulting from the line of energy production of coal and the production of territory which determines it in terms of a common logic and thus territorializing [7] each of the processes involved in this transformation of coal and, therefore, strengthened its impact from the 1930s.

The "anthropogeographical landscape" [8] took on importance in the understanding of the legacy which resulted from the construction of the territory from the energy production of coal. Contrary to the factory, this legacy stems from the relationship that the industry established with the location and was determined by the rationality imposed by its productive cycles.

It is in the territorialization [7] of this production system and the surrounding relations-commercial, hierarchical, etc., which involves the anthropogenic and environmental components of constructions-based on mining heritage and are very often disregarded given the absence of architectural value concerning each of the objects turn this into a system.

Along with the heritage underlying contemporary existence [9] and ability to represent "values and needs that establish links between the present and past, giving coherence to a world in constant transformation" [10] (p. 9) there is an understanding of the landscape, as a result of history of the 
place [11], although not always intelligible due to the temporal and spatial overlap that characterizes the sediments_of buildings but also natural, topographic and geological elements, political projects and decisions, and technological advances-which constitute this [12].

This reading of the formation processes of the territory over a given time period, as shown in Figure 2, enables the identification of "structural invariants" [13], permanent elements, material, and logical sediments and provides the ability to lead not to the conservation of each of the physical structures involved in this system but to the conservation and reproduction of the territorial identity [7]. Based on the place structure, this territorial identity is always determined by "support and intervention, with the mutual relation they establish" [14] (p. 116).
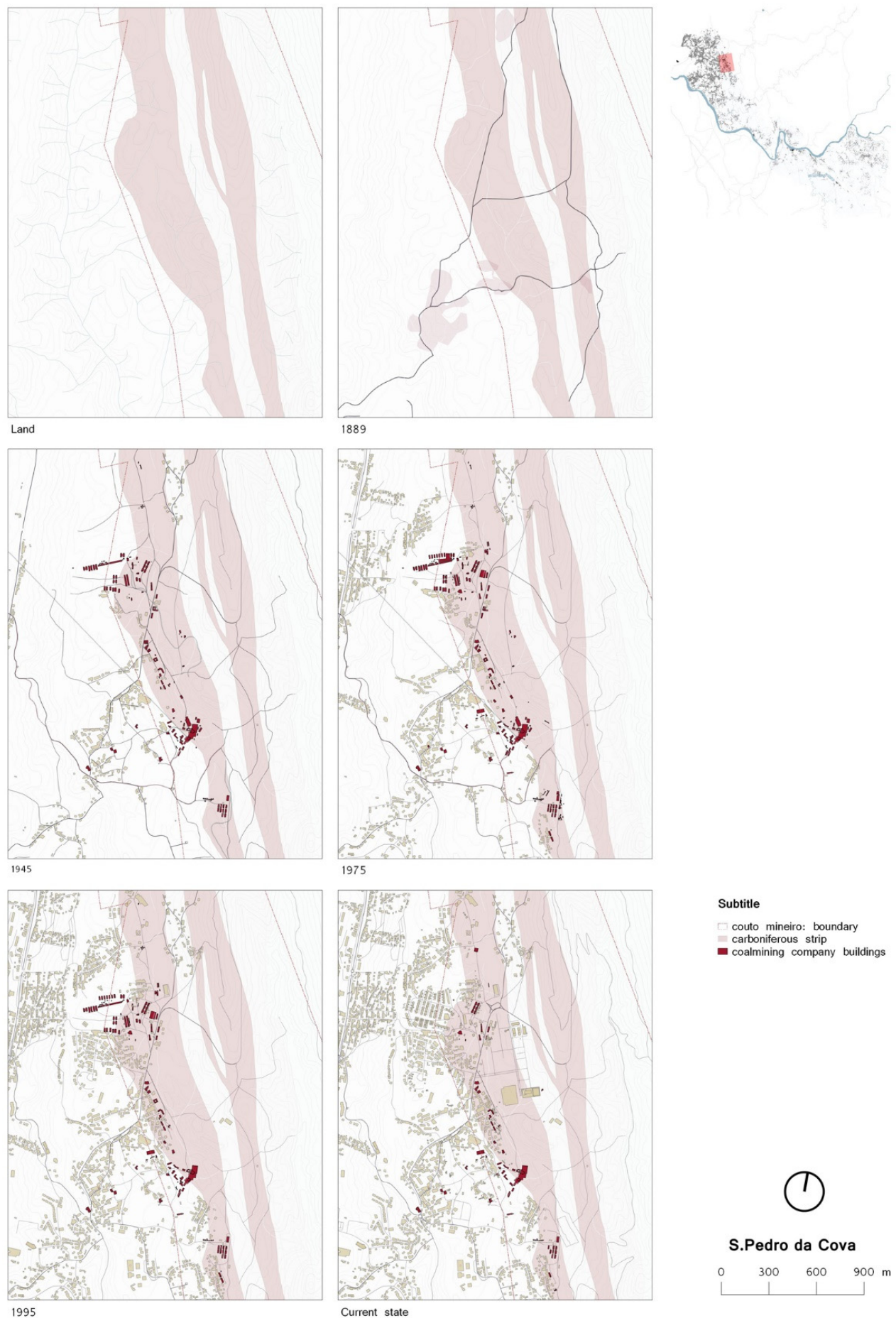

Subtitle
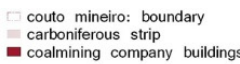

Figure 2. The evolution of the coal settlement of S. Pedro da Cova. 
It is an understanding of heritage as a living entity which is evolving and consequently complex to be valued by its referential meaning and its transformative potential.

The relocation of energy sources due to the European political context underlying the global market has dismantled this productive system and leaves the territory structured by coal mining in abeyance.

Territories particularly depressed by the abandonment to which they were condemned have had the fragments resulting from this dismantlement submitted to new transformation logics, which are not linked to such "invariants" that have given it the identity and values of its roots that the population attributes to them.

This formalized heritage, through the transformation of the landscape, is now understood institutionally as a strategic vector for territorial planning both internationally [15] and nationally [16] although acknowledges the weakness of its instantiation [17].

In the $\mathrm{BCD}$ this strategic vision for territorial development is formalized in municipal territorial planning instruments (Plano Municipal de Ordenamento do Território (PMOT)) $[18,19]$, in the Reservoir Development Plan for Crestuma-Lever (Plano de Ordenamento da Albufeira de Crestuma-Lever (POACL)) [20], and through the Urban Rehabilitation Operations (Operação de Reabilitação Urbana (ORU)) which is underpinned by integrated interventions aimed at the urban rehabilitation of particularly degraded areas, although in practice it occurs through a quasi-exclusive perspective of intervention works by private individuals on the housing stock [21].

Applied to Italian territorial management instruments since 1995 [22], the understanding that "structural invariants" will respond to the need to transpose relations and the processes that support them rather than guarantee safeguards concerning cultural assets.

Incorporating a forward-looking vision which envisages respectful transformation processes of the territory and its history [13] (p. 169) this concept brings us then to spatial planning based on the understanding of the landscape [23] which is already targeted in contexts where the regional administrative structure has a greater importance, e.g., Spain, Italy [24,25], and the European Landscape Convention (2000), which are all framed more consistently both in the territorial management instruments and in the legal framework of cultural heritage [26].

We are faced with a territory in which the cultural peculiarities inherent in the largely invisible rules that have supported its construction are particularly important for its patrimonial recognition.

With a patrimonial safeguard present in territorial management tools since 1982 and with the institution of the legal figure of the Municipal Master Plan (Plano Director Municipal (PDM)) [17], an effort will be made to consider the "structural invariants" under the instruments for territorial planning and management in force and to reach a conclusion concerning the effective integration of the patrimonial aspect in territorial transformation policies.

\section{Materials and Methods}

To identify the SCD fragments which best represent the mining legacy while taking into account the different territorial management structures to which they have been subjected and the criteria outlined by UNESCO with respect to the attribution of outstanding universal value [27]:

- The key role they played in SCD, not only due to the productive structures involved but also due to the urban structure they established and constituted (criterion ii, iii);

- The concentration of representative structures within a given period and the form of building due to a technological response to the productive structure (criterion iv);

- The recognition of the population when confronted with the patrimonial identification and its documental characterization (authenticity);

- The conservation up to the present day of most of the constituent structures of the core able to be organized as such (integrity). 
Systematizing the framing of these cores within the scope of the urban management instruments in force through their reading and georeferencing [28]. The use of geographic information systems (GIS)—QGIS Desktop 2.18.17—enabled not only the territorialization of data related to the SCD itself-the geological structure base of SCD, the settlements evolution as a result of the productive system of energy from coal, the relationship between these settlements and topography and water resources, the SCD marks still on the territory, the change on settlement logics after the closure of mining activity, etc. - but will also produce related and relational information [29] to further analyze the territory based on its heritage resources.

To analyze how the "structural invariants" for SCD are integrated within the territorial planning and management tools.

To reach a conclusion concerning the integration of this heritage structure within territorial transformation policies and to understand the different perspectives of territorial management that integrate it in accordance with the logic of management determined by each municipality.

\section{Results}

From the nuclei which form part of the SCD, according to the previously established criteria, two have been selected: S. Pedro da Cova, Gondomar; and, Germunde, Castelo de Paiva.

Both correspond to the central nuclei of Couto Mineiro de S. Pedro da Cova and Pejão including "mining works accessories" [30] which established urban settlements, supported within the administrative, and the functional and economic autonomy of the Coutos Mineiros. These are the nuclei by which it is possible to recognize a model of urbanization-imported-through which it was sought to optimize productive processes while, on the other hand, to respond to the problems introduced by a rapid industrialization process [31] (Figure 3). They represent the "success of a long-lasting historical process" [7] (p. 152).

The nucleus of S. Pedro da Cova is covered by the PDM of Gondomar [19] and forms part of the urban rehabilitation area (Área de Reabilitação Urbana (ARU)) of S. Pedro da Cova e Fânzeres [32]; Gemunde is covered by the POACL [20] and by the PDM of Castelo de Paiva [18], which does not form any part of a the ARU defined for the Council [33].

Within the scope of the PMOTs, the nucleus of S. Pedro da Cova includes an area of "Rural Soil: Cultural spaces" [19], which includes the Cavalete de S. Vicente, Monument of Public Interest [34], and its special protection zone (Zona Especial de Protecção (ZEP)), as seen in Figure 4. Together with the nucleus of the Tapada do Outeiro thermal power plant (Central Termoeléctrica da Tapada do Outeiro (CTTO)), which is also part of the SCD, these are presented as the only "Cultural Spaces" of the Municipality [19] in considering "the installation of collectively used equipment (...) that encourage visits to them and their collective use as areas with an identity involving mining activity in the council" [19] (p. 7580).

With regard to the PDM of Castelo de Paiva, published in the year following the closure of the Pejão Mines, there is no safeguarding in the heritage and/or cultural domains with regard to the permanent features resulting from mining activity which is understood in the nucleus of Germunde as "Urban and Urbanizable Spaces" in part "consolidated" and in part "for urban expansion" [18] (Figure 5).

The current safeguard came into force only in 2007, with the POACL, concerning the riverside front of Castelo de Paiva and part of Gondomar at which time Germunde, like the aforementioned CTTO, was entitled "Areas of protection and valorization of resources and specific values: Protection Area, Area of Special Cultural Interest" [20], as shown in Figure 5 becoming "the subject of an integrated project for recovery of the area, and enabling construction works aimed at converting the space into museum units" [20] (p. 9031).

In 1995, it was recognized that more than any heritage safeguard, the mining issue was considered due to the alterations provoked in the subsoil, identifying within the "coal mining concession areas" the "mining subsistence areas" [18] (Figure 5). In S. Pedro da Cova, 46 years after the closure of 
the mines this geomorphological issue raises an environmental aspect, identifying the area related to the delimitation of the Couto Mineiro de S. Pedro da Cova as "Geological Resources-Areas in recovery" [19] (Figure 4).

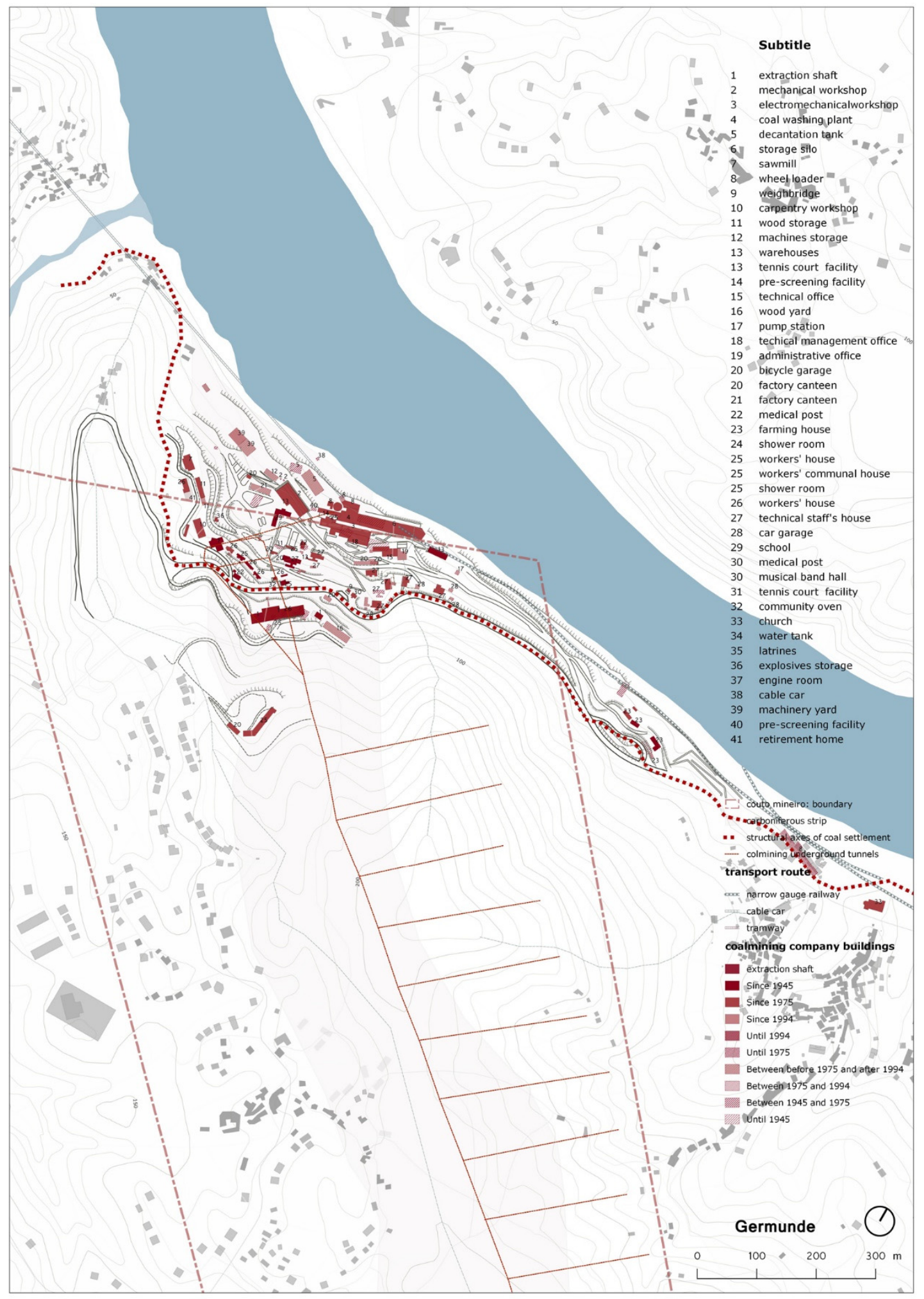

Figure 3. The Germunde coal settlement. 


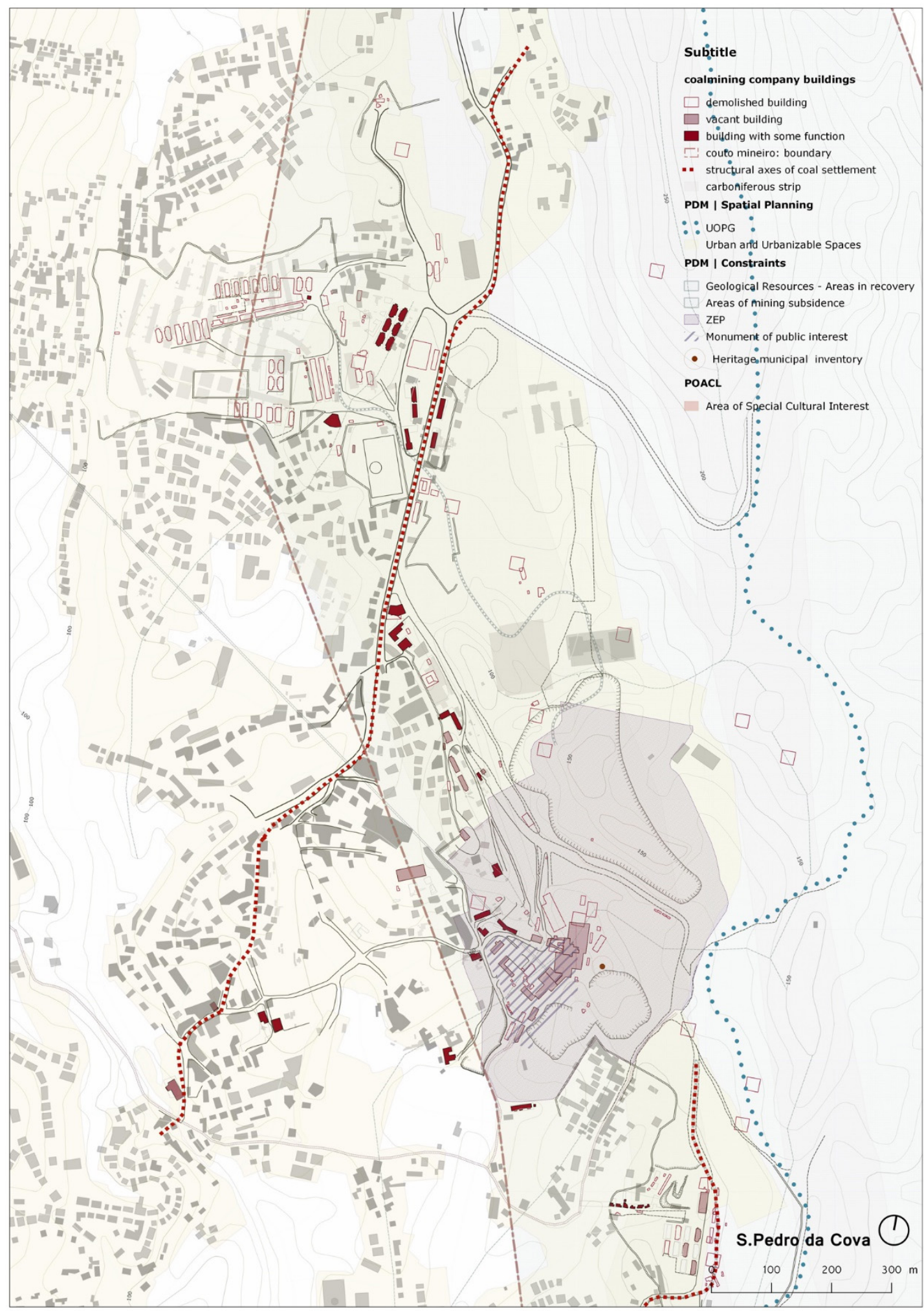

Figure 4. The territorial management instruments on the S. Pedro da Cova coal settlement. The operational management unit (Unidade Operativa de Planeamento e Gestão (UOPG)) does not include the coal settlement. The area in recovery and the Couto Mineiro boundary are overlapping. 


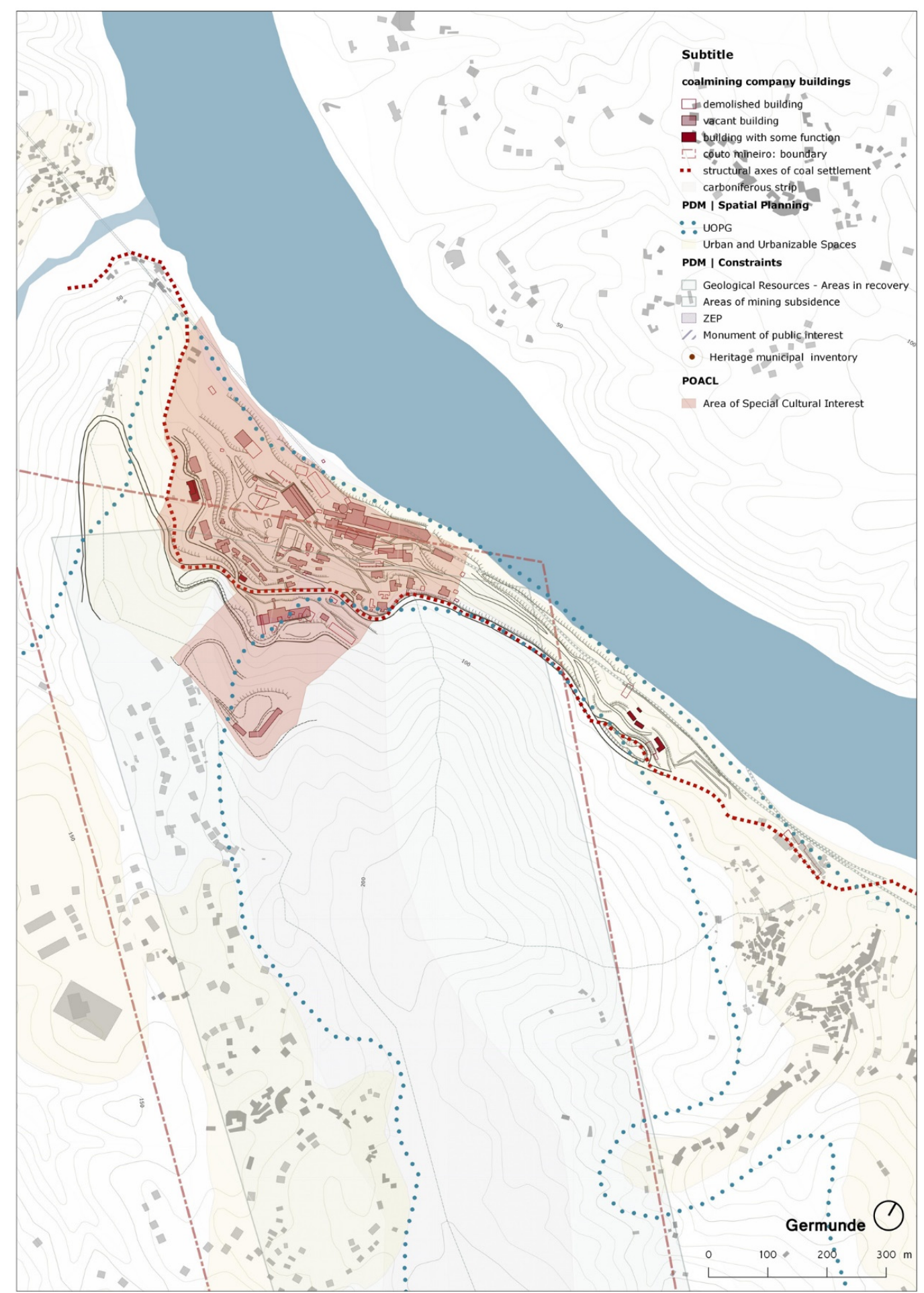

Figure 5. The territorial management instruments on the Germunde coal settlement. The difference between the Couto Mineiro boundary and areas of mining subsidence is probably due to an imprecision in the 1995 charter.

With the introduction of the Urban Rehabilitation Juridical Scheme (Regime Jurídico de Reabilitação Urbana (RJRU)), the rehabilitation of the "degraded or degrading urban fabric" was encouraged [21] (p. 4462) and at the same time trying to "ensure the protection and promoting the valorization of the cultural heritage" [21] (p. 4462) and "affirm heritage, material and symbolic values as factors of identity, differentiation and urban competitiveness" [21] (p. 4462). This context defines the ARU 
of S. Pedro da Cova e Fânzeres (2018) [32]—which partially covers the nucleus of S. Pedro da Cova integrated within the SCD-as shown in Figure 6, and Pedorido (2017) which is juxtaposed to the nucleus of Germunde without forming part of it (Figure 7).

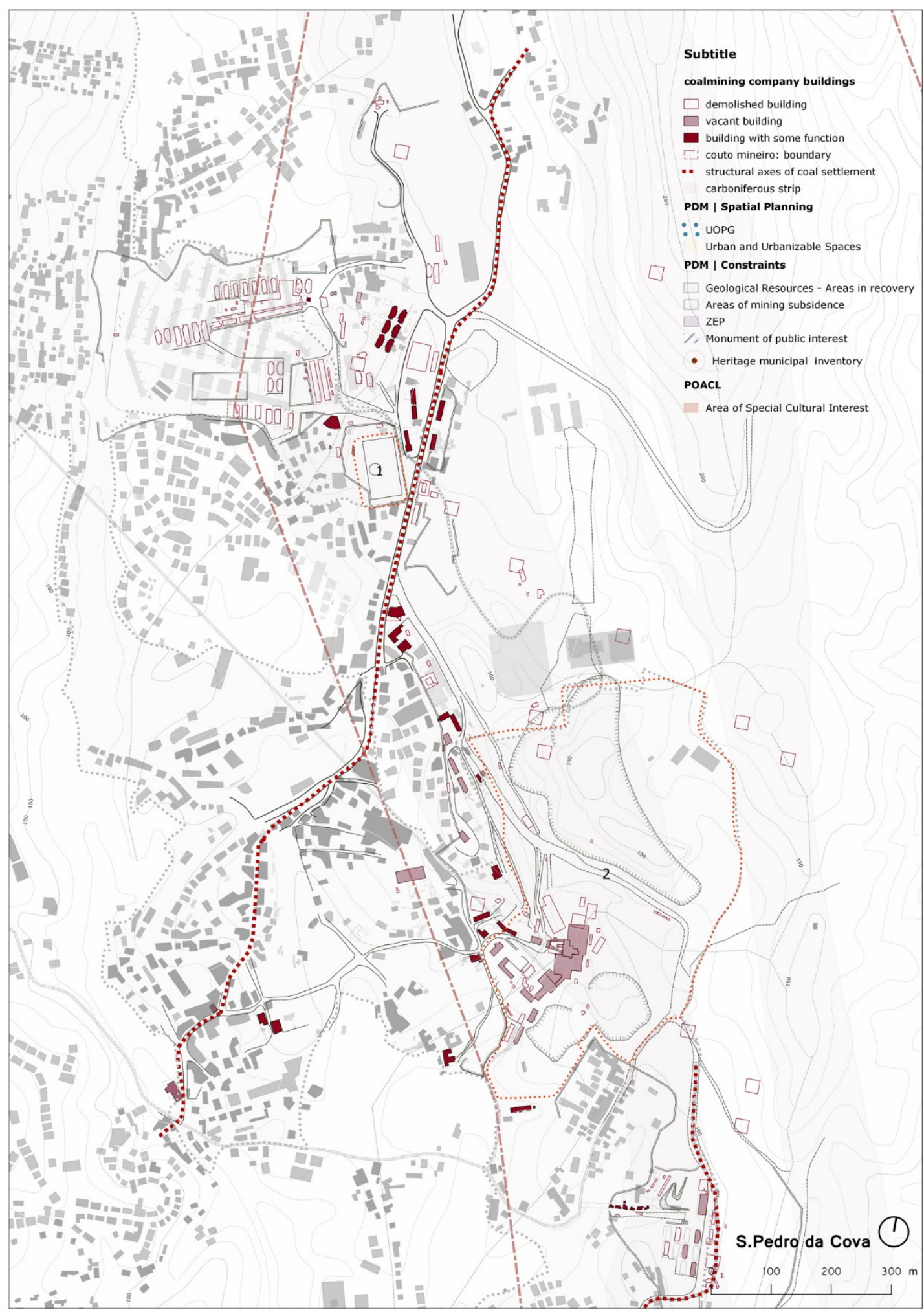

Figure 6. The Strategic Urban Rehabilitation program in the S. Pedro da Cova coal settlement. ARU of S. Pedro da Cova e Fânzeres. 


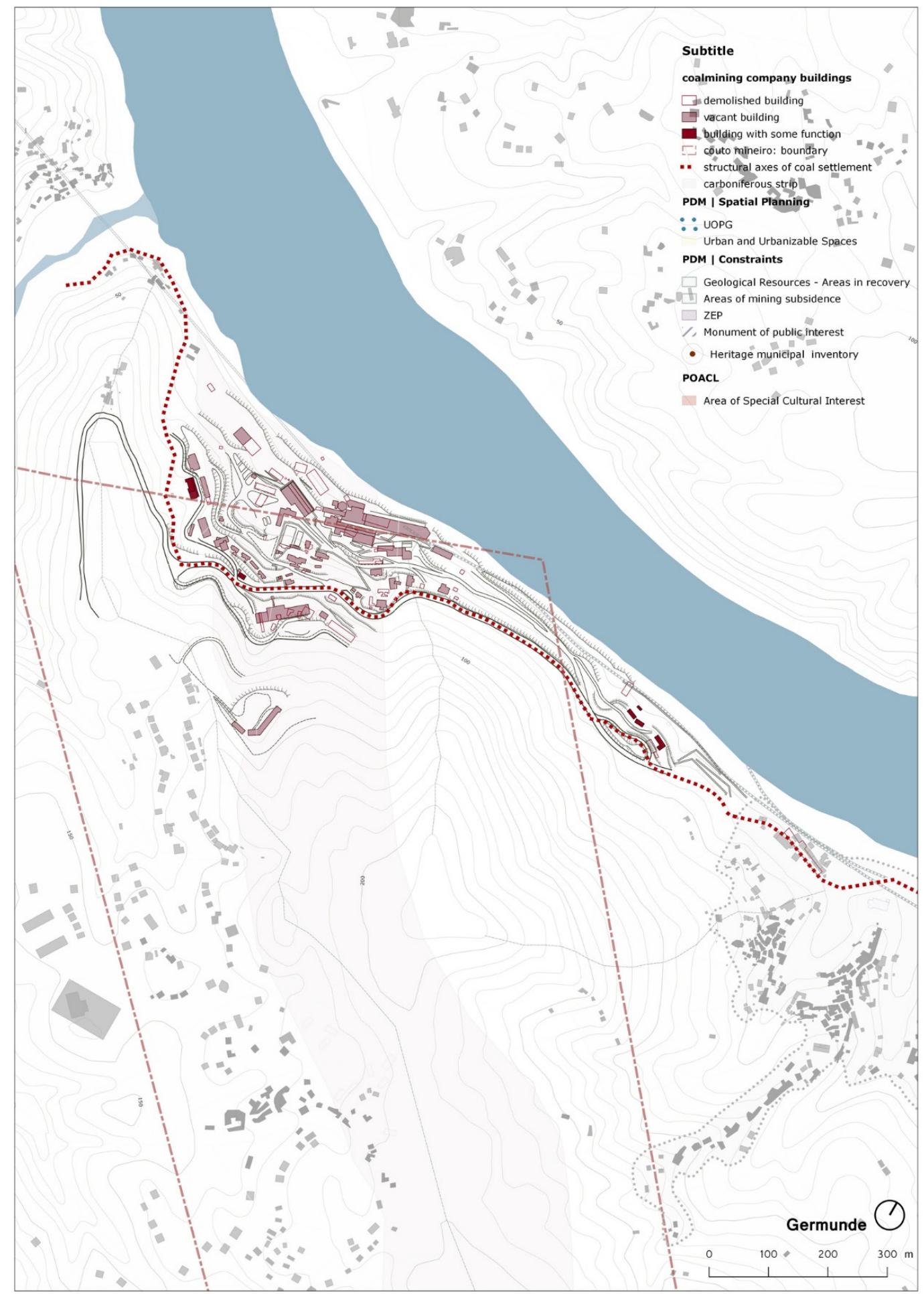

Figure 7. The Strategic Urban Rehabilitation Program in the Germunde coal settlement. The ARU of Pedorido.

The ORU associated with the ARU forming part of the nucleus of S. Pedro da Cova envisages the "Musealization of the Mining Facilities of S. Pedro da Cova" [32] thus creating a "hub of cultural and tourist attraction" [32] (p. 15) to be linked to another yet to be created structure in the CTTO and the Massarelos thermal power plant, which also forms part of the SCD. There is also the reconversion of the former football stadium of the Companhia das Minas de S. Pedro da Cova into an urban park. 
Outside of this ARU, there are a series of structures that are part of the urban nucleus determined by the coal industry particularly facilities (health centre, medical post, water tank), structural axes of the coal settlement, etc., as shown in Figure 6.

In the case of the Pedorido ARU [33], there is no integration of the urban nucleus created by coal mining, joining only a few structures built by the Empresa Carbonifera do Douro (the church of Pedorido, iron railway-bridge, former rail-boat interface, and soccer fields), although without making any reference to the coal structure in this context and without a perspective of intervention other than in the public area of the riverside front, as seen in Figure 7.

\section{Discussion}

Through the systematization of the planning and territorial management instruments, as shown in Table 1, as far as the most representative nuclei of the SCD are concerned, it was seen that:

- The Carboniferous structures are recognized within a heritage understanding both through its classification as "Monument of Public Interest", in the case of the Cavalete de S. Vicente and surrounding area (S. Pedro da Cova), as shown in Figure 4, and as "Area of Special Cultural Interest (Área de Especial Interesse Cultural (AEIC))" (POACL) in the case of the Germunde core, as shown in Figure 5.

- The concept of heritage takes on distinct shapes [35] gaining greater weight in the territorial management instruments of the current generation of PDM. At the same time, this investment in heritage as a factor of differentiation and territorial competitiveness [21] is affirmed by the definition of ARU, as exemplified by ARUs in or near the nuclei addressed.

- The SCD fragments are not understood within a wholistic logic but rather, within a piecemeal view determined by the individual value of each of the physical structures inherent to this system. The idea of landscape as a result of history acting on the territory [36] loses power in the context of land planning and thus equating the heritage issue in a disjointed way to the logics that structured it as such, as shown in Figure 8.

Table 1. The urban management instruments in the coal settlements of BCD: Synthesis.

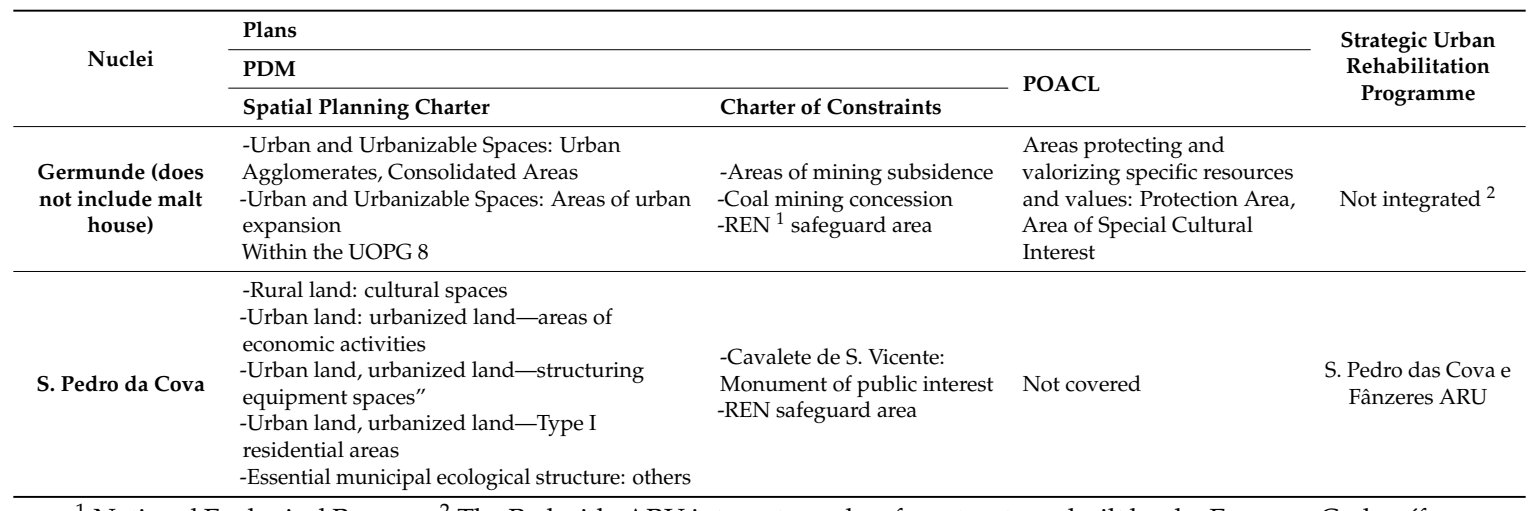

${ }^{1}$ National Ecological Reserve; ${ }^{2}$ The Pedorido ARU integrates only a few structures built by the Empresa Carbonífera do Douro. 


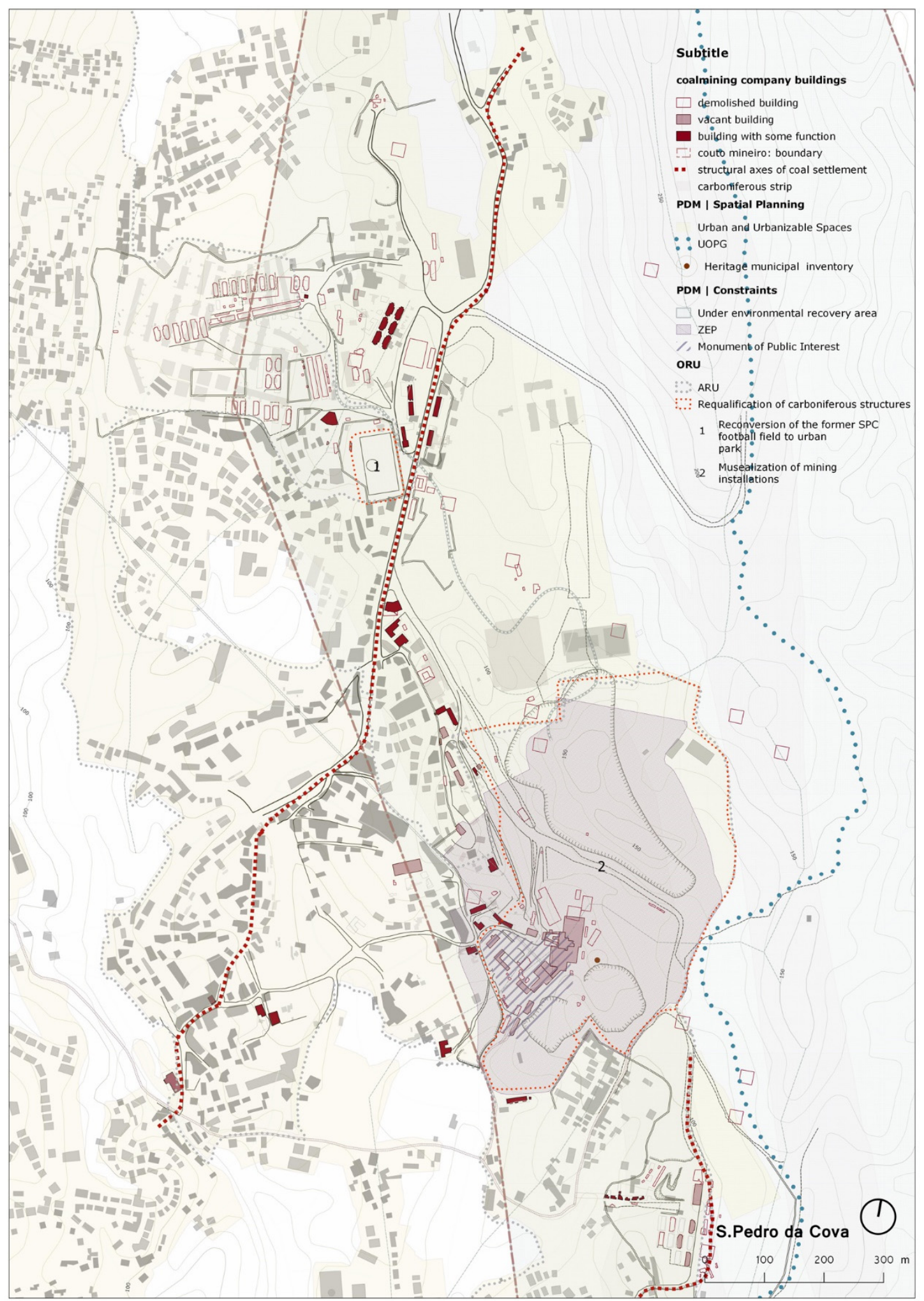

Figure 8. The territorial management instruments and strategic urban rehabilitation program in the S.

Pedro da Cova coal settlement. The ARU of the S. Pedro da Cova e Fânzeres and the Gondomar PDM.

The disparagement of the logics of landscape construction is also shown through the delimitation of the ARU and the programming of the AEIC as museological units. This intervention strategy is removed from the idea of the whole: In S. Pedro da Cova the reading of the urban settlement as being determined by coal activity is lost by not considering spaces other than those of work, as shown in 
Figure 6; in Germunde, contrary to the guidelines of the TICCIH (The International Committee for the Conservation of the Industrial Heritage) [37] for the understanding of the industrial heritage, the urban settlement resulting from such operations is isolated destroying its reading as an integral part of a productive territorial system in scope, as shown in Figure 5.

This approach is in line with the Portuguese cultural heritage law [38], still object-oriented, in the understanding of landscape being not so consequent on the instruments for its management; unlike the territorial management instruments that integrate the "structural invariants", they are assumed as a response to a cultural heritage law in which the landscape presents itself as a structure to enhance [24].

- The "structural invariants" [13] which determined the territory and the identifying role which the population assigned to them are integrated into the planning and land management instruments in a passive manner being given a rather inconsequential, although binding, role in endogenous development. This is referring to the built structures but also to logistics involving the connectivity and articulation of different centralities [39] by which the SCD determined.

- An understanding of the rules of growths linked to the identity of each place as enhancing transformation would be a valid response to the envisaged urban renewal [18] extending the intervention in buildings and promoting individual and collective re-appropriation of the place.

- The autonomy that allowed the nuclei to develop as a centrality concentrated around key functions and agglutinating the structures that guaranteed a response to the daily life of those who inhabited it and gives rise to hierarchical and disjointed nuclei within the municipal structure with little consequence for the guarantor in the quality of life.

- The priority given to urban fabrics to be renewed is influenced by the financing instruments, one of the most determining factors on landscape transformation currently [40]. Within the 2020 funding framework ARU on the riverfront, as shown in Figure 7, Abandoned Industrial Areas and Historical Centers (through Instrumento Financeiro para a Reabilitação e Revitalização Urbanas (IFRRU)) have been given priority [41]. Hence, in the ARU delimitation that was referred to it was hardly articulated with the logics of the structuring of urban settlement and the risk that in a few years there will be a series of "ghost" structures/equipment, without promoting any effective rehabilitation of the urban fabric within which they are integrated (Figure 9).

- There are no operational units capable of covering the logistics of construction/transformation of the territory in a unitary and systemic way and encompassing a municipal vision. As a unit to program the transformation of the territory this should be subjugated to a planning logic determined by its construction [23], underlying the understanding of the SCD landscape. Although provided for in the Legal Regime of Territorial Management Instruments (Regime Jurídico dos Instrumentos de Gestão Territorial (RJIGT)) [42], the intermunicipal scope that should be thought of concerning territorial transformation has not yet been considered and has already happened in countries with regional self-governments [22,25]. 


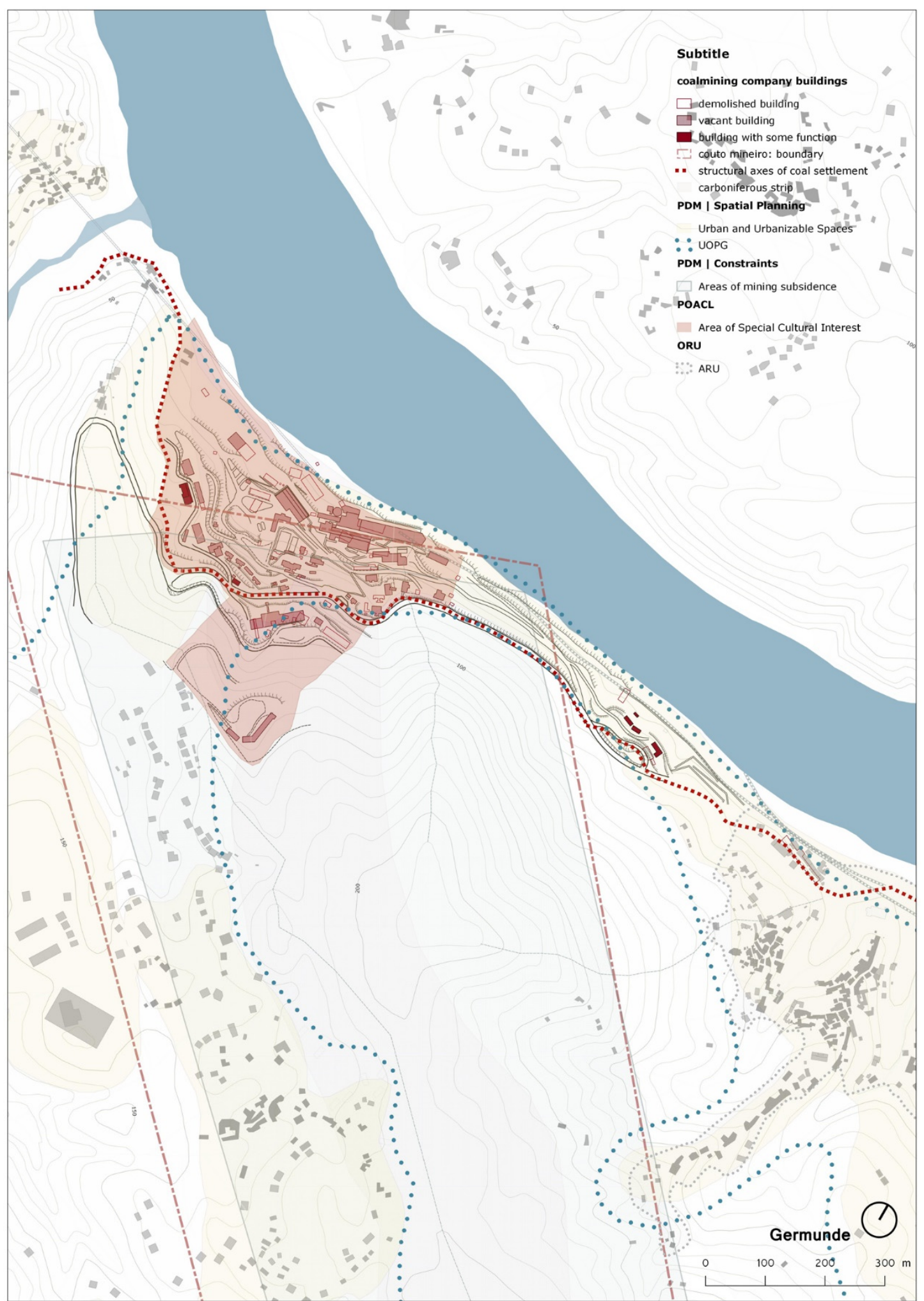

Figure 9. The territorial management instruments and strategic urban rehabilitation program in the Germunde coal settlement. The ARU of the Pedorido, Castelo de Paiva PDM and the POACL.

\section{Conclusions}

Given a territory particularly determined by a logic of unified construction, in this case due to an economic activity which is already defunct, the question of heritage takes on a territorial dimension which leads us to think of its intervention based on an understanding of "anthropogeographical 
landscape". Consequently, the understanding of heritage ceases to make sense if understood objectively, disconnected from its understanding as an integral part of a system.

Transposing this question to the instruments that determine the planning and management of the territory, it is necessary to change the paradigm regarding intervention in/from heritage: A conservation binding certain assets to be worked on to move on to a conservation and valorization of the structural aspects of the territory in seeking to attribute an active role in development to heritage-social, economic, cultural, etc.-of the fabric of which it partly forms.

In the particular case of the $\mathrm{BCD}$ coal structures, the current territorial planning and management instruments are hardly aware of the underlying logic of their construction consisting of disjointed and one-off interventions that are not conducive to their development which are now subdued to new paradigms of technological and economic mobility.

Thinking about a strategy valuing the mining legacy implies the reorganization of the physical—and social—space based on strategies capable of integrating this into the current dynamics in order to reconstruct a livable system which is capable of increasing the value that those structured around it have given.

This perspective of transformation, based on the recognition and valorization of the identity of the places, considered as an endogenous resource and only then exogenous, should promote the development of local society.

As a tool, inclusive territorial planning and management processes which go beyond municipal management are capable of (re)producing territorializing actions which enhance and are supported on heritage stimulating a valorization of the concomitant landscape of local development.

Funding: This research was funded by the Portuguese Foundation for Science and Technology, grant number BD-SFRH/BD/118409/2016 through the Operational Human Capital Program, supported by the European Social Fund and national funds of the MCTES.

Acknowledgments: The author would like to thank the research supervisors Madalena Pinto da Silva and Lino Tavares Dias, the technicians in the Division of Planning and GIS of the Municipality of Gondomar, and those of the Planning and Urban Planning Division of the Municipality of Castelo de Paiva for making the territorial management documents referred to in the article available.

Conflicts of Interest: The authors declare no conflict of interest.

\section{References}

1. Ivancic, A. Energyscapes; Gustavo Gili: Barcelona, Spain, 2010; ISBN 9788425222726.

2. Nadaï, A.; van der Horst, D. Introduction: Landscapes of Energies. Landsc. Res. 2010, 35, 12. [CrossRef]

3. Alves Ribeiro, D. Territories of energy production and landscape heritage. The Coal Basin of Douro. Joelho, Revista de Cultura Arquitectónica 2015, 6, 162-170. [CrossRef]

4. Alves Ribeiro, D. (Infra)estruturas de Produção Energética. O Carvão no Sistema Urbano do Porto; Grant Report of the Programa Millennium de Bolsas de Investigação na Área da Cidade e da Arquitetura, 2016; Fundação da Juventude, Ordem dos Arquitectos, Município do Porto, Milenium BCP: Porto, Portugal, unpublished.

5. Lemos de Sousa, J.M. Contribuição para o conhecimento da Bacia Carbonífera do Douro. Dissertação de Doutoramento em Geologia, Universidade do Porto, Porto, Portuga, 1973.

6. Macedo, M. Projectar e Construir a Nação. Engenheiros, Ciência e território em Portugal no século XIX; Imprensa de Ciências Sociais: Lisboa, Portugal, 2012; ISBN 9789726712954.

7. Magnaghi, A. Il Progetto Locale. Verso la Coscienza di Luogo; Bollati Boringhieri Editore: Torino, Italy, 2017; ISBN 9788833921501.

8. Gregotti, V. Il Territorio dell' Architettura; Feltrinelli: Milano, Italy, 2008; ISBN 9788807720017.

9. Rossa, W. Património Urbanístico: (Re)fazer Cidade Parcela a Parcela; Sumário Pormenorizado da lição Apresentado para Provas de Agregação; Universidade de Coimbra: Coimbra, Portugal, 2012.

10. Choay, F. L'urbanisme: Utopies et Réalités. Une Anthologie; Éditions du Seuil: Paris, France, 1979; ISBN 9782020053280.

11. Sauer, C.O. La morfología del paisaje. Polis, Revista de la Universidad Bolivarian 2006, 5, 15. 
12. Corboz, A. El territorio como palimpsesto. In LO Urbano; Martín Ramos, Ángel, Ed.; Edicions de la Universitat Politécnica de Catalunya, Ed.: Barcelona, Spain, 2004; ISBN 8483017520.

13. Maggio, M. Invarianti Strutturali nel Governo del Territorio; Firenze University Press: Firenze, Italy, 2014; Volume 22, ISBN 9788866556299.

14. Barba, R. El Proyeto del Lugar. In Rosa Barba Casanovas. 1970-2000. Obras y Escritos; AS Flor Ediciones: Barcelona, Spain, 2010; pp. 114-124. ISBN 9788461438013.

15. Territorial Agenda of the European Union 2020; Toward an Inclusive, Smart and Sustainable Europe of Diverse Regions; Agreed at the Informal Ministerial Meeting of Ministers responsible for Spatial Planning and Territorial Development; European Union (EU): Gödöllő, Hungary, 2011.

16. PNPOT, Alteração. Uma Agenda para o Território (Programa de Ação); Território, Direcção Geral do Território: Lisboa, Portugal, 2018.

17. Henriques, E.B. Opatrimónio nas Políticas Territoriais. In Proceedings of the V Congresso da Geografia Portuguesa; Portugal: Territórios e Protagonistas, Guimarães. Available online: http:/ /www.apgeo.pt/files / docs/CD_V_Congresso_APG/web/_pdf/E5_14Out_Eduardo\%20Brito\%20Henriques.pdf (accessed on 30 November 2018).

18. Plano Director Municipal de Castelo de Paiva (Resolução de Conselhos de Ministros n. ${ }^{6}$ 68/1995); Diário da República I Série- B, n. ${ }^{\circ} 163$; Governo de Portugal: Lisboa, Portugal, 1995.

19. Alteração do Plano Diretor Municipal de Gondomar (Aviso n. ${ }^{\circ} 3337 / 2018$ ); Diário da República, 2. ${ }^{\text {a }}$ Série-N. ${ }^{\circ}$ 51; Governo de Portugal: Lisboa, Portugal, 2018.

20. Plano de Ordenamento da Albufeira de Crestuma-Lever (Resolução de Conselhos de Ministros n. ${ }^{\circ}$ 187/2007); Diário

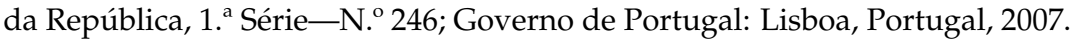

21. Regime Jurídico da Reabilitação Urbana (Lei, n. ${ }^{\circ}$ Lei n. ${ }^{\circ}$ 32/2012); Diário da República n. ${ }^{\circ}$ 157/2012, 1. ${ }^{\text {a Série; }}$ Governo de Portugal: Lisboa, Portugal, 2012.

22. Norme per il Governo del Territorio, Proposta di Legge Regionale (L. R n. ${ }^{\circ}$ 5/1995); Bollettino Ufficiale della Regione Toscana - n. 6; Giunta Regionale della Toscana: Firenze, Italy, 1995.

23. Regole e Progetti per il Paesaggio. Verso il Nuovo Piano Paesaggistico Della Toscana; Poli, D. (Ed.) Università degli Studi di Firenze, Facoltà di Architettura: Firenze, Italy, 2012; ISBN 9788866551577.

24. Piano Paesaggistico Territoriale Regionale della Puglia; Bollettino Ufficiale della Regione Puglia - n. 40; Giunta Regionale della Puglia: Bari, Italy, 2015.

25. Pla Director Urbanístic de les Colònies del Llobregat. Géneralitat de Catalunya; Departament de Politica Territorial Obres Publiques, Direcció General d’Urbanisme. Comissiò d' Urbanisme de Catalunya: Barcelona, Spain, 2007.

26. Codice dei beni Culturali e del Paesaggio; Decreto Legislativo n. 42, del 22 gennaio; Repubblica Italiana: Roma, Italy, 2004.

27. The Operational Guidelines for the Implementation of the World Heritage Convention; UNESCO World Heritage Centre: Paris, France, 2017.

28. Box, P. GIS and Cultural Resource Management: A Manual for Heritage Managers; Dixon, S., Ed.; UNESCO: Bangkok, Thailand, 1998.

29. Cordovez, R.R.T. Aplicaciones Informaticas al Proyecto Urbano; Universidad Politécnica de Valencia: Valencia, Spain, 2008; ISBN 9788483632543.

30. Legislação Mineira; Decreto n. ${ }^{\circ}$ 18713/1930; Direcção Geral de Minas e Serviços Geológicos, Governo de Portugal: Lisboa, Portugal, 1930.

31. Alves Ribeiro, D. Estruturas territoriais do carvão: Do espaço produtivo ao espaço social. In Proceedings of the X Congresso Docomomo Ibérico: O Fundamento Social da Arquitetura; do Vernáculo e do Moderno, uma Síntese Cheia de Oportunidades, Badajoz, Spain, 18-20 April 2018. accepted.

32. Operação de Reabilitação Urbana de S. Pedro da Cova e Fânzeres; Município de Gondomar: Gondomar, Portugal, 2018.

33. Programa Estartégico de Reabilitação Urbana; Município de Castelo de Paiva: Castelo de Paiva, Portugal, 2017.

34. Classificação do Cavalete de S. Vicente como Monumento de Interesse Público (Portaria n. ${ }^{\circ}$ 221/2010); Diário da

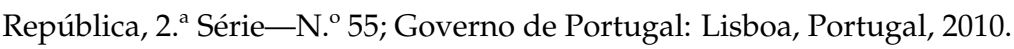

35. Tarrafa, A. Historic Urban Landscape approach and spatial planning. Exploring the integration of heritage issues in local planning in Portugal. Dissertação de Mestrado, Instituto Superior Técnico, Lisboa, Portugal, 2017. 
36. Zampieri, L. Per um Progetto nel Paesaggio; Quodlibet: Macerata, Italy, 2012; ISBN 9788874624416.

37. Vanderhülst, G. Industry, man and Landscape. In Proceedings of the TICCIH Congress 1990, Industry, Man and Landscape, Bruxelles, Belgium, 3-8 September 1990; pp. 28-50.

38. Lei de Bases do Património Cultural (Lei n. ${ }^{\circ}$ 107/2001); Diário da República n. ${ }^{\circ}$ 209/2001, Série I-A; Governo de Portugal: Lisboa, Portugal, 2001.

39. Portas, N. Da Estratégia ao Projecto. In Nuno Portas, Escritos 1975-2012. Os Tempos das Formas; Volume II: A -cidade Imperfeita e a Fazer; Oliveira, I., Bandeira, P., Eds.; Escola de Arquitectura da Universidade do Minho: Guimarães, Portugal, 2012; pp. 87-101. ISBN 9789899616356.

40. Il Paesaggio nel Governo del Territorio: Riflessioni sul Piano Paesaggistico Della Toscana; Morisi, M.; Poli, D.; Rossi, M. (Eds.) Firenze University Press: Firenze, Italy, 2018; ISBN 9788864536699.

41. Programa de Ação IFRRU 2020; Estrutura de Gestão do Instrumento Financeiro para a Reabilitação e Revitalização Urbanas: Lisboa, Portugal, 2017.

42. Regime Jurídico dos Instrumentos de Gestão Territorial (Lei n. ${ }^{\circ}$ 80/2015); Governo de Portugal: Lisboa, Portugal, 2015.

(C) 2019 by the author. Licensee MDPI, Basel, Switzerland. This article is an open access article distributed under the terms and conditions of the Creative Commons Attribution (CC BY) license (http://creativecommons.org/licenses/by/4.0/). 